\section{A Cyclotron at the Science Museum}

Prof. E. O. Lawrence, of the University of California, has very kindly lent to the Science Museum the cyclotron, built by himself and Livingston in 1931, with which his first nuclear transmutation work was carried out in 1932. With an applied oscillating potential of only 4,000 volts peak, this instrument was capable of accelerating protons to a speed equal to that produced by a fall through $1,200,000$ volts. The instrument was slightly modified afterwards by M. G. White for experiments on the scattering of protons in hydrogen, and in this modified form it has now been placed on exhibition in the Science Museum in close proximity to Cockeroft and Walton's original apparatus, which accelerated protons through 600-700 kilovolts by means of a D.C. voltage of this amount derived from a transformer through a special voltage-multiplying rectifier circuit. Prof. Lawrence has also lent to the Museum a small collection of photographs illustrating the development of the cyclotron. One of these shows the two preliminary cyclotron models built by Lawrence and Edlefsen in 1930, which, though relatively crude, gave encouragement for further development because they showed resonance effects; a further photograph shows the original cyclotron of Lawrence and Livingston, which accelerated hydrogen molecular ions through 80,000 volts with an applied highfrequency potential of less than 2,000 volts; and a series of views illustrates the latest cyclotron of Lawrence and Cooksey, which delivers currents of the order of 100 micro-amperes of deuterons with energies in the neighbourhood of 8 million volts, or a beam of alpha-particles of about one micro-ampere at 16 million volts.

\section{Waterspouts off the British Isles}

WATERSPOUTS are not such rare phenomena in the seas around the British Isles as is sometimes supposed. Many of those that have been observed from coast stations of the Meteorological Office far out at sea at times when few people are in the neighbourhood have doubtless been recorded only at the Meteorological Office. This applies especially to those seen in waters off the main shipping routes. With the rapid increase of continental air services and the R.A.F. expansion, opportunities of observation have multiplied, and statisticians of the future may have to be on their guard against accepting as real any sudden apparent increase of waterspout activity that may be shown during the re-armament period. Apart from this, there has been the slower growth of seaside population in the last thirty or forty years. The four waterspouts seen off the sea-front at Bexhill on September 1 would almost certainly have been unrecorded had they occurred before that period, although some farm labourer might have returned to his native village after his day's work in the fields overlooking the sea to recount over his pint of beer how he had seen the Devil in the form of a fourtrunked elephant leaning out of a thundercloud to drink out of the sea and how the Foul Fiend's breath had hung like a cloud over the surface of the sea as he drank. Those readers who wish to know more about the phenomenon can consult a work by Alfred Wegener called "Wind und Wasserhosen in Europa" (Braunschweig, 1917), or an account of a discussion by the late M. A. Giblett of a paper by the same author in the official Meteorological Magazine for April 1929. The waterspout is a well-known manifestation of the tornado, and is replaced by a 'dust devil' if the tornado passes from the water to a dusty land surface.

\section{Institute of Brewing Researches}

Srr Gilbert Morgan, director of chemical research in the Department of Scientific and Industrial Research, has been appointed chairman of the Research Fund Committee of the Institute of Brewing. For many years the Institute has been carrying out researches covering a wide range chiefly in connexion with the raw materials of brewing, namely, barley, hops and yeast, which have been carried out in collaboration with numerous experts and with the following institutions, namely, East Malling Research Station (East Malling), Imperial Council for Agricultural Research (India), Municipal College of Technology (Manchester), National Institute of Agricultural Botany (Cambridge), Rothamsted Experimental Station (Harpenden), SouthEastern Agricultural College (Wye); and in the University of Birmingham. The offices of the Institute are at Brewers' Hall, Addle Street, London, E.C.2. It will be recalled that Sir Gilbert's impending retirement from his post under the Department of Scientific and Industrial Research was recently announced (see Nature, July 30, p. 200).

\section{Power Supply in Small-Scale Industries}

THE Vienna Sectional Meeting of the World Power Conference, which was concluded on September 2, was most successful. Of the thirteen British papers presented, four are concerned with power supply to small-scale industries. An important paper on this subject was presented by J. N. Waite, electrical engineer of Hull, and F. H. Clough, of the British Thomson-Houston Co., Ltd. They point out that the market depends on the particular district served. If the local supply undertaking finds it economic to encourage such uses as cooking, water heating and space heating, then the demand for power will probably be large. They estimate that the total market for the uses covered in their paper is of the order of 11 thousand million units per annum. Distribution methods are becoming standardized and new uses for electrical energy are steadily arising. Attention is directed to the change in the economic position that may follow active development of what are now normally 'off-peak' demands, provided new peak demands are created. The authors emphasize the value of flexible tariffs, as these promote uses which ereate 'diversity in demand'. Judicious expenditure on canvassing is considered wise. The paper concludes with observations on the influence of taxation upon tariffs. A paper by Mr. W. Dieterichs, of the Gas Light and Coke Company, deals with "Gas for Small-Scale Industries". He stated that the gas industry has developed from a manufacturer and seller of a commodity into a specialized heat service. 